\title{
Prototype Development of Myoelectrics Signal-Based Exoskeleton
}

\author{
Anggrian Riska Amelia Shabrine ${ }^{1}$, Pujiyanto ${ }^{1}$, Akif Rahmatillah ${ }^{1, a)}$ \\ ${ }^{1}$ Department of Physics, Faculty of Science and Technology, Universitas Airlangga, Surabaya 60115, Indonesia \\ a) Corresponding author: akif-r@ fst.unair.ac.id
}

Article History

Received : 03 March 2021, Revised : 09 April 2021, Accepted : 16 April 2021, Online : June 2021

\begin{abstract}
Diffable is incompleteness or abnormality accompanied by consequences for specific functions. The method used is tapping on the hamstring and hamstring muscles quadriceps to determine the resulting voltage-muscle signal tapping using Electromyograph (EMG) and $\mathrm{Ag}-\mathrm{AgCl}$ electrodes. Average current-voltage contraction and relaxation are used as threshold values to drive the servo motor. This study indicates the tension when the muscle contracts are in the range of 4 volts while the relaxation time is 0.4 volts. Then it can be concluded that the voltage when the muscle is contracted is more significant than when it is relaxed. Using different tension during contraction and relaxation in normal subjects showed that the different tension could drive the prototype exoskeleton.
\end{abstract}

\section{INTRODUCTION}

According to data from the National Socio-Economic Survey (SUSENAS) in 2004, the number of people with physical disabilities in Indonesia reached 1.6 million people. Based on the Indonesian Ministry of National Health (Kemenkes) data in 2011, people with disabilities were at 6.7 million people or around 3.11\%. Meanwhile, according to the World Health Organization (WHO), people with disabilities in Indonesia reach more than 10 million. Technological developments require a person to have reasonably high mobility. With these demands, good physical condition is critical to be carried out optimally. The foot is one of the most important members of the body that functions as a supporter of mobility. With perfect feet, a person can do any activity according to their wishes. Physical disability means a condition that is damaged or disturbed due to impaired shape or inhibition of bones, muscles, and joints in their normal function. This condition can be caused by illness, accident or it can also be caused by innate nature (Soemantri, 2006). Disabilities are caused by various factors, including heredity, infection, trauma, tumors, accidents, and other conditions [3]. To determine whether the muscles in these disabled people still have the same function as before, they can use an Electromyograph (EMG) to analyze.

Electromyography (EMG) is a medical device that functions to record and evaluate the extracellular electrical potential generated by muscles [2]. The measured Electromyogram (EMG) signal can determine which parts of the muscles are contracting and which parts of the muscles are relaxing. With the Electromyogram (EMG) signal pattern, it can be used as the control of a walker. Exoskeletons are mobility aids designed for a variety of situations. This exoskeleton helps people living with paralysis so that they can walk again as usual.

This research designs and makes an exoskeleton prototype using readily available materials to be implemented in the long term. Based on research conducted by Verlinden et al. in 2011 [7], which resulted in control algorithms for lower limb orthosis, prostheses, and exoskeletons, especially the ankle. This study discusses the logarithm used to move the exoskeleton. Not only that, this study discusses the mechanics and controls used to move the exoskeleton. This study produced a prototype exoskeleton made of acrylic, which intercepts Electromyogram (EMG) signals using a surface electrode.

Electromyography (EMG) is used to analyze the tension generated by the muscles. Research that the author has carried out uses the lower limbs, especially the thighs. Previously, electrodes were placed on the two muscles, namely the hamstring and quadriceps muscles. From these muscle signals, it can move the prototype of the artificial leg. The prototype is installed with a servo motor so that the prototype can move in flexion or extension. 


\section{METHOD}

Human muscle activity is tapped using a surface electrode. The result of muscle activity is a signal that has a range ranging from millivolts to microvolts. Then the signal will be amplified to a volt by the instrumentation amplifier circuit. In the signal, there is still noise coming from the power source, which is $50 \mathrm{~Hz}$. Therefore, a Notch Filter circuit is added so that it can eliminate these frequencies. The Notch Filter circuit can be shown in Figure 1.

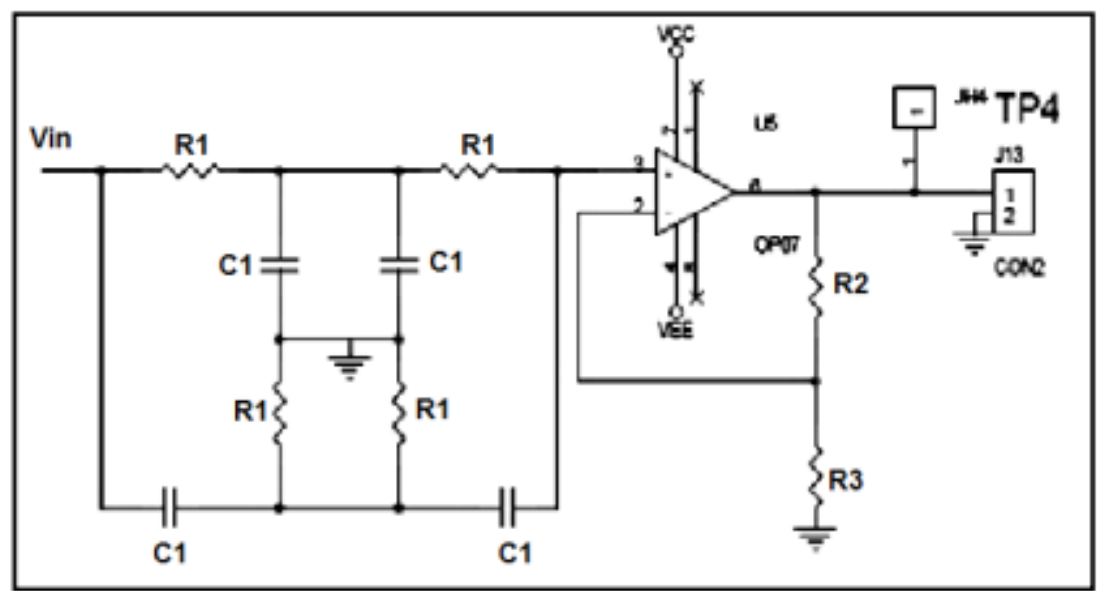

FIGURE 1. Notch Filter Circuit

Next, perform another filter by using a series of first-order High Pass Filters, shown in Figure 2.

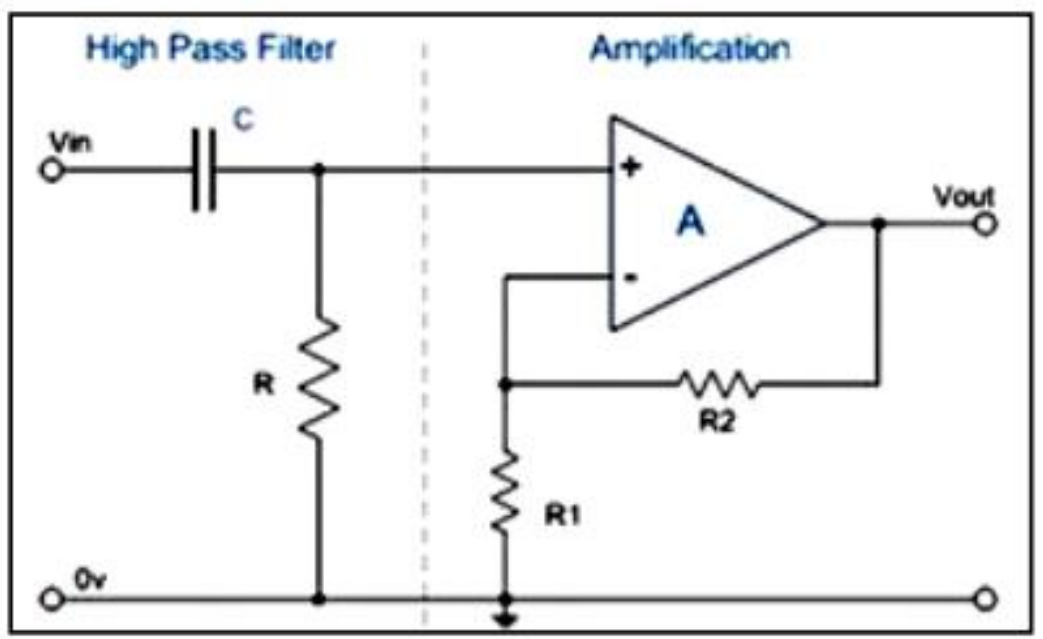

FIGURE 2. High Pass Filter Circuit

Then proceed with adding a rectify circuit so that the signal obtained can be all positive. After that, the signal with a positive value is inserted into the smoothing circuit to be better. The entire hardware circuit has been completed. Then the muscle signal is obtained, which was initially worth microvolts to volts. Then connect to the Arduino, which has been connected to the PC with the help of a data cable. The voltage value can be read on a PC to be connected to the LabVIEW software. The value given by Arduino is displayed in graphical form with the help of

LabVIEW software. After the graph appears, the threshold value of each muscle movement is obtained. With this threshold value, the amount of angle that LabVIEW emits to the motor is determined. The threshold limit is used as a reference for the movement of the motor. It affects the acrylic movement that has been made. When a hamstring muscle has a signal above the threshold and the quadriceps muscle has a value below the threshold, the motor moves in flexion movement and vice versa.

\section{RESUlts AND DISCUSSIONS}

There are two kinds of electromyography (EMG) made with circuits and components the same because each Electromyograph (EMG) can measure only one muscle. Input from the circuit is obtained from the quadriceps and 
muscles hamstrings. The movement of the two opposing muscles causes a movement in the feet. When the quadriceps muscles contract and the hamstring muscles relax, it causes extension movement. On the other hand, when the quadriceps relax, the hamstring muscles relax the contract, and the leg moves flexibly. Electromyography (EMG) Design shown in Figure 3.

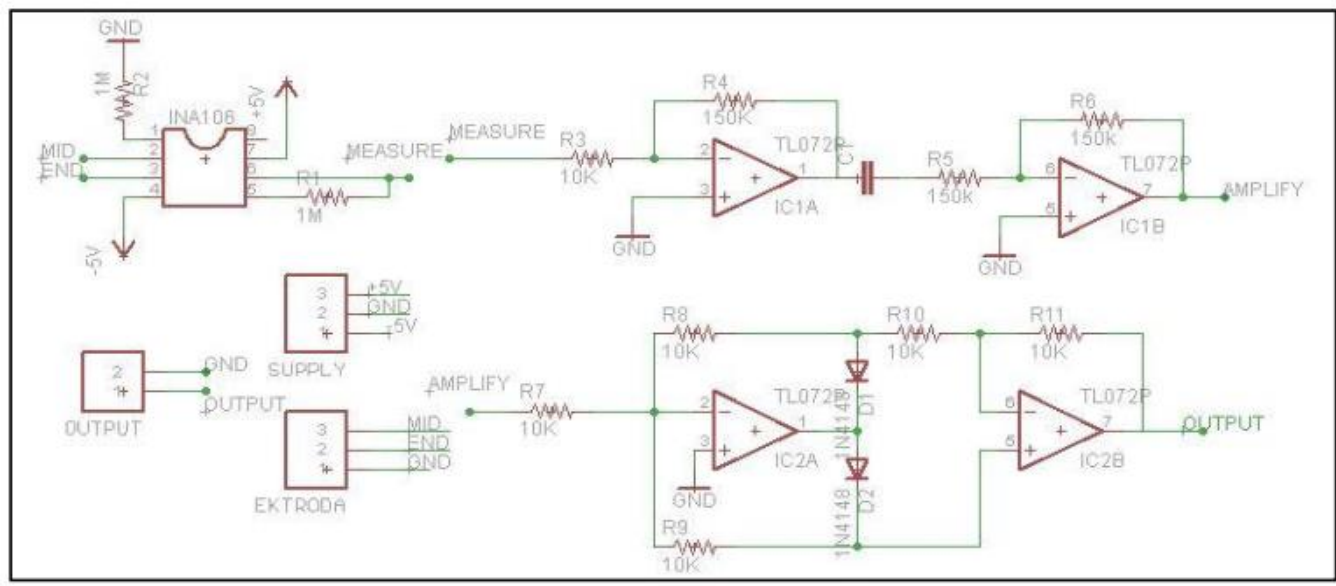

FIGURE 3. Electromyography (EMG) Design

The test results of the instrumentation amplifier circuit used in this study are shown in Figure 4.

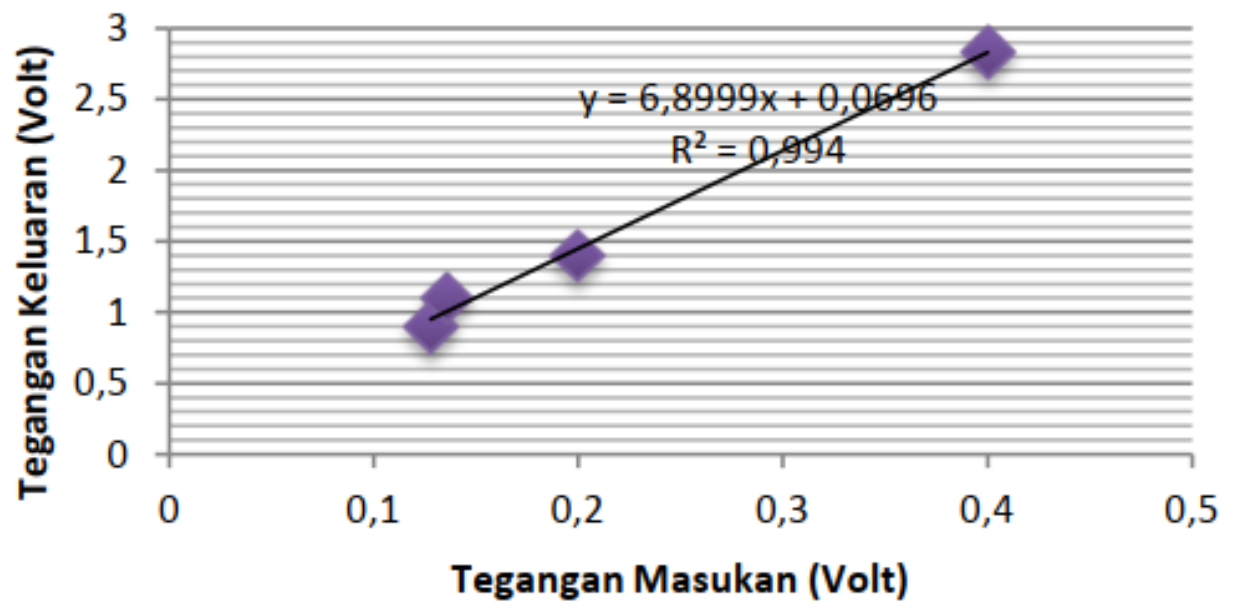

FIGURE 4. Results of instrumentation amplifier linear regression

The results of the High Pass Filter (HPF) test are shown in the Bode Diagram in Figure 5.

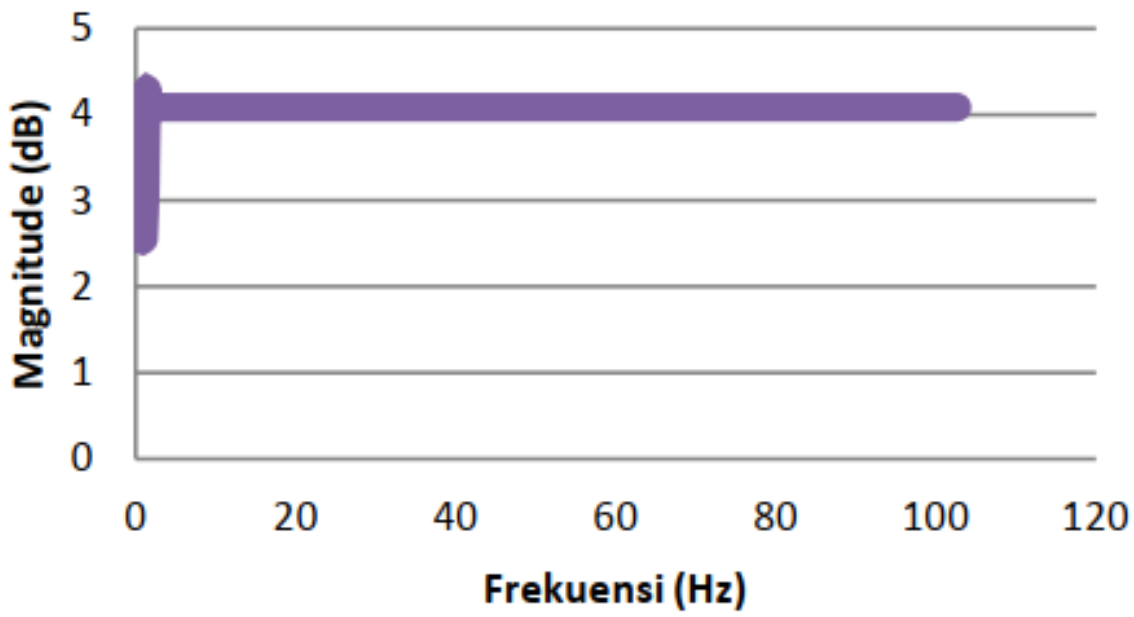

FIGURE 5. Bode diagram of the High Pass Filter test 
The test results of the Notch Filter circuit can be seen in Figure 6.

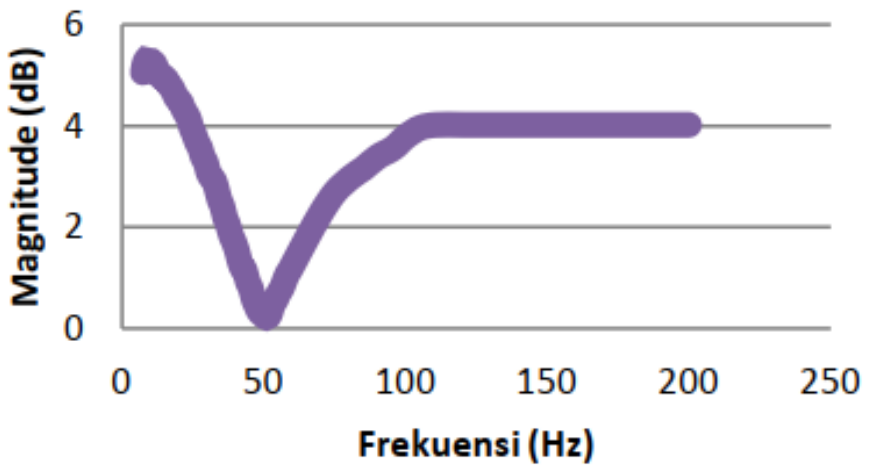

FIGURE 6. Bode diagram of the Notch Filter test

The Electromyograph (EMG) final result is connected to LabVIEW to be displayed on the Personal Computer (PC) screen, as shown in Figure 7. Average test results on the hamstring muscles and quadriceps muscles of three female participants are presented in Table 1.

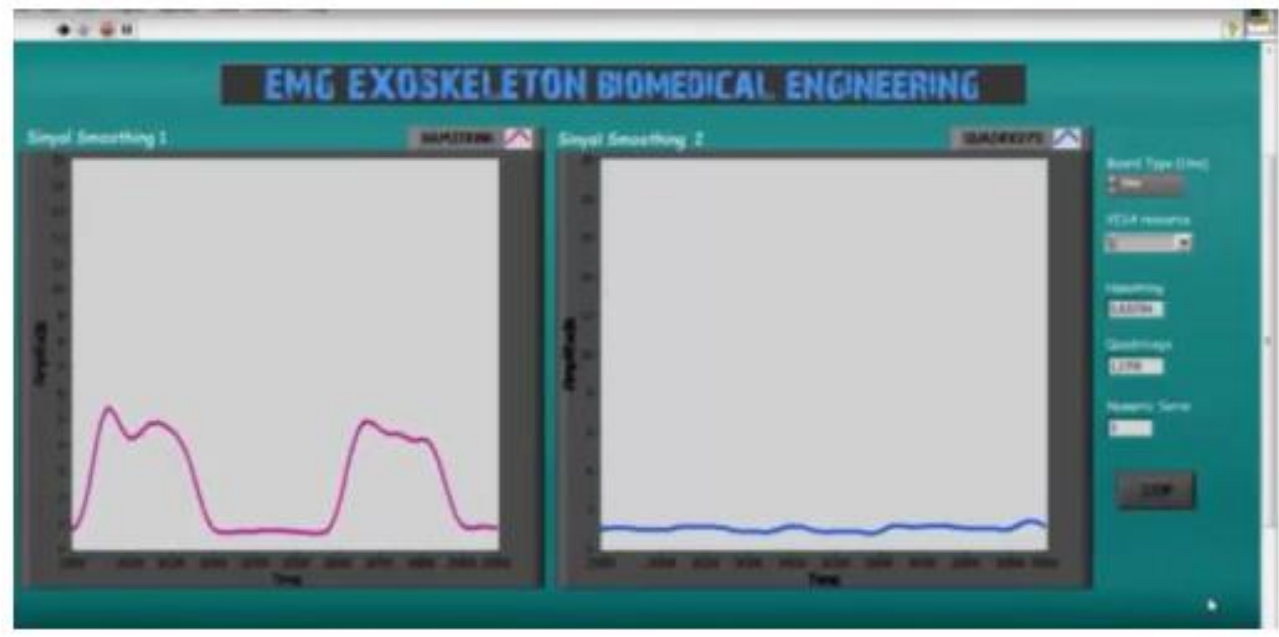

FIGURE 7. Display of the final Electromyograph (EMG) on LabVIEW

TABLE 1.. Specific Functional Groups of IBS Paste

\begin{tabular}{ccccc}
\hline Naracoba & $\begin{array}{c}\text { Rerata Tegangan } \\
\text { pada otot } \\
\text { quadriceps saat } \\
\text { relaksasi (volt) }\end{array}$ & $\begin{array}{c}\text { Rerata Tegangan } \\
\text { pada otot } \\
\text { quadriceps saat } \\
\text { kontraksi (volt) }\end{array}$ & $\begin{array}{c}\text { Rerata Tegangan } \\
\text { pada otot } \\
\text { hamstring saat } \\
\text { relaksasi (volt) }\end{array}$ & $\begin{array}{c}\text { Rerata Tegangan } \\
\text { pada otot } \\
\text { hamstring saat } \\
\text { kontraksi (volt) }\end{array}$ \\
\hline Rata-rata & $0,45 \pm 0,059$ & $4,73 \pm 1,16$ & $0,42 \pm 0,13$ & $4,55 \pm 0,82$ \\
\hline
\end{tabular}

After obtaining the tension in each muscle, then determine the threshold used as an indicator so that the servo motor can move. Determination of this threshold is done manually by finding the average of the tension in the hamstring and quadriceps muscles. The average of the two is then searched for the median value to obtain the threshold value. The function of the threshold is as a threshold at which the motor changes in motion.

The data acquisition design using LabVIEW and connecting the Electromyograph can be seen in Figure 8. The prototype exoskeleton made can only move in flexion (90o) and extension (0o). Flexion movement is obtained when the hamstring muscles contract and the quadriceps muscles relax, shown in Figure 9a. The extension movement occurs when the hamstring muscles relax and the quadriceps muscles contract, shown in Figure 9b. 


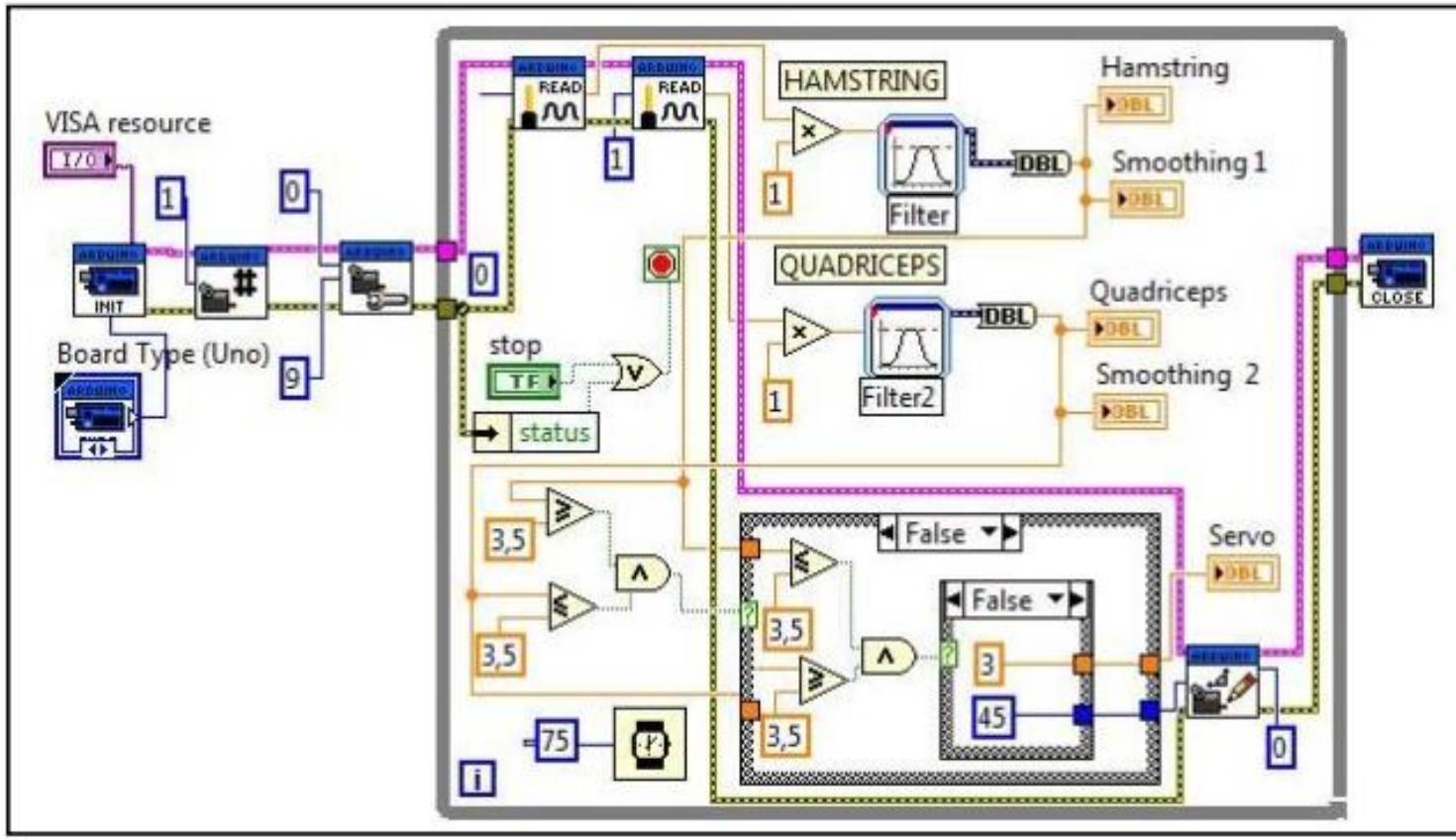

FIGURE 8. Electromyography (EMG) data acquisition design with servo motor
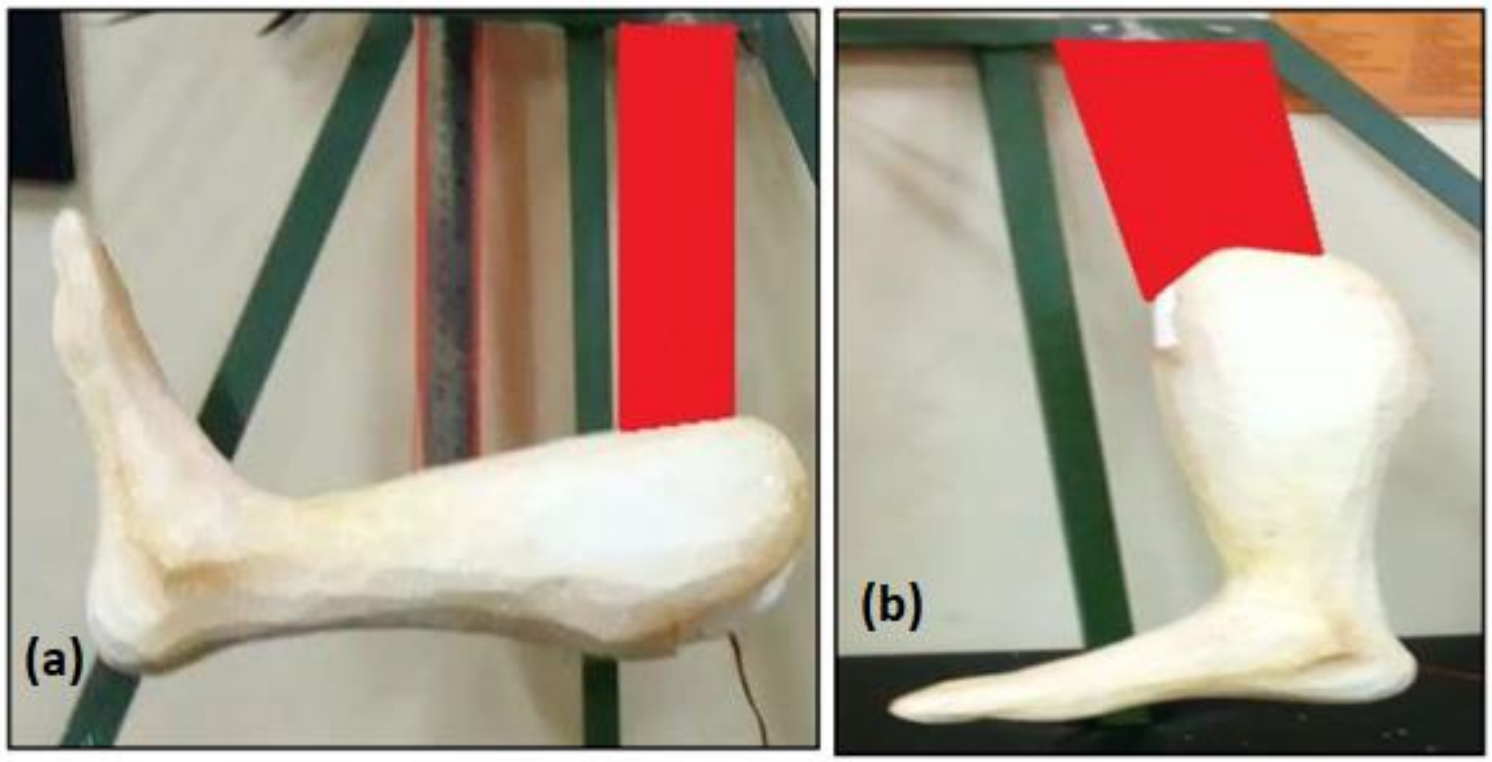

FIGURE 9. (a). Exoskeleton prototype flexion movement, (b). Exoskeleton prototype extension movement

Several factors affect the difference in the angle produced by each person, one of which is the placement of electrodes on each muscle (Akay.M, et al., 2004). In addition, the factors that affect muscle endurance are age, gender, physical activity, nutrient intake, and nutritional status (Ministry of Health, 1996). Due to the participants' different physical activities, each participant's muscle strength was also different. These physical activities are brisk walking, running, cycling, swimming, and physical activities related to muscle strength (Hapsari, 2011).

\section{CONCLUSION}

1. There is a difference in the myoelectric signal when the muscle contracts and relaxes. When the quadriceps muscle relaxes, the resulting voltage is 0.45 volts, but it shows 4.73 volts when it contracts. As the hamstring muscles, when relaxed, the tension is 0.42 volts and during contraction reaches 4.55 volts.

2. Differences in myoelectric signals in the hamstring and quadriceps muscles can move the exoskeleton prototype. 


\section{REFERENCE}

1. Artanto,Dian, 2012, Interaksi Arduino dan LabVIEW, Jakarta: PT Elex Media Komputindo Crecraft. David and Gergely. Stephen, 2002, Analog Electronics Circuits, Systems and Signal Processing, UK : Elsevier Science

2. Fougner.Anders Lyngvi, 2007, Proportional Myoelectric Control of a Multifunction UpperLimb Prosthesis, Canada: Norwegian University of Science and Technology, Department of Engineering Cybernetics

3. Iryani.Detty, 2013, Fisiologis Otot, Padang : Kuliah Pengantar, Kedokteran UNAND Nasirin, 2010, Kebermaknaan Hidup Difabel, Yogyakarta: Fakultas Dakwah, Universitas Islam Negeri Sunan Kalijaga

4. Nomiyasari, 2011, Perancangan dan Pembuatan Modul ECG dan EMG dalam Satu Unit PC, Surabaya: Jurnal Jurusan Teknik Elektro. Politeknik Elektronika Negeri Surabaya, Kampus PENS-ITS.

5. Pack.Phillip, 2007, Anatomi dan Fisiologi, Bandung : Pakar Raya

6. Rizzoni.Giorgio, 2005, Principles And Applications Of Electrical Engineering, Fifth Edition, USA: McGraw-Hill Science

7. Verlinden.O,et.al, 2011, Review of Control Algorithms for Robotic Ankle System in LowerLimb Orthose, Prostheses, and Exoskeletons. Belgium : Service de Mecanique

8. Rationnelle, Dynamique et Vibrations, Faculte Polytechnique, Universite de Mons

9. Webster.John G, 1999, The Measurement, Instrumentation and Sensors, CRC Press 